\title{
Obszary intensywnych powiązań funkcjonalnych miast na prawach powiatu w Polsce - autorska metoda delimitacji \\ Areas of strong functional linkage of Polish cities granted county status - the authors' own method of delimitation
}

\author{
Dariusz Ilnicki Krzysztof Janc \\ Uniwersytet Wrocławski \\ Instytut Geografii i Rozwoju Regionalnego \\ ul. Kuźnicza 49/55, 50-138 Wrocław \\ dariusz.ilnicki@uwr.edu.pl•krzysztof.janc@uwr.edu.pl
}

Zarys treści. Mobilność przestrzenna ludności jest kluczowym czynnikiem umożliwiającym dokonywanie delimitacji obszarów funkcjonalnych i identyfikacji zasięgów oddziaływania jednostek przestrzennych. Głównym celem opracowania jest identyfikacja obszarów intensywnych powiązań funkcjonalnych dla miast na prawach powiatu. Wskazanie tych obszarów opiera się na ogólnodostępnych danych, a mianowicie statystyce dojazdów do pracy najemnej oraz migracji wewnętrznych na pobyt stały. Identyfikacja obszarów intensywnych powiązań funkcjonalnych jest wypadkową: (1) obszarów emigracji i imigracji miasta na prawach powiatu, dla których odpowiednio jest on źródłem i celem migracji wewnętrznych na pobyt stały; (2) obszarów wyjazdów i dojazdów do pracy, do i z danego miasta na prawach powiatu, przy uwzględnieniu dodatkowych warunków dotyczących relacji pomiędzy wielkościami przepływów w układzie miasto na prawach powiatu - obszar wiejski. Analiz dokonano na poziomie NUTS 5 z pominięciem miast nieposiadających statusu miasta na prawach powiatu. Wobec funkcjonujących w literaturze przykładów sposobów identyfikacji obszarów powiązań funkcjonalnych dla polskich miast, niniejsze opracowanie może stanowić płaszczyznę dyskusji dotyczącej podejść alternatywnych. Zaprezentowane podejście ma na celu przedstawienie autorskiej metody identyfikacji obszarów intensywnych powiązań funkcjonalnych z perspektywy mobilności przestrzennej ludności. Wyniki przeprowadzonych analiz wskazują, że zidentyfikowane według autorskiej metody obszary intensywnych powiązań funkcjonalnych w dużym stopniu nawiązują do miejskich obszarów funkcjonalnych ośrodków regionalnych. Istotnym elementem dla proponowanego podejścia jest jego całkowite zobiektywizowanie czy też brak arbitralnych decyzji. Jest to sytuacja pożądana w przypadku powtórzeń badań.

Słowa kluczowe: mobilność, migracje, delimitacja, Polska.

Keywords: mobility, migration, delimitation, Poland.

\section{Wstęp}

Dokładność opisu otaczającej nas rzeczywistości uzależniona jest od dostępności danych, ich jakości, szczegółowości, aktualności. Zawartość merytoryczna dostępnych danych oraz (dez)agregacja przestrzenna (jednostki odniesienia przestrzennego) wpływają na precyzję opisu zjawisk. Należy zwrócić uwagę, że w przypadku wielu zjawisk występują ograniczenia możliwości ich opisu przede wszystkim ze względu na kwestie dostępności danych. Jednymi z takich zagadnień są te związane z przemieszczaniami ludności. Poznanie ich jest ważne zarówno z perspektywy poznawczej, jak i praktycznej. Jak zauważa Clark (2008), na- 
uka o przestrzeni jest nauką o zachowaniach w przestrzeni. Stąd też podstawą rozumienia większości zjawisk związanych z funkcjonowaniem układów przestrzennych jest poznanie cech mobilności przestrzennej ludności, uchwycenie jej prawidłowości przestrzennych. Podkreślić należy, że dla ujęcia praktycznego to właśnie mobilność przestrzenna ludności jest kluczowym czynnikiem umożliwiającym dokonywanie delimitacji obszarów funkcjonalnych i identyfikacji obszarów oddziaływania jednostek przestrzennych. Możliwość określenia prawidłowości przestrzennych w tym zakresie wpływa na trafność podejmowanych działań planistycznych i prorozwojowych.

Głównym celem opracowania jest identyfikacja obszarów intensywnych powiązań funkcjonalnych dla miast na prawach powiatu. Wskazanie tych obszarów opiera się na ogólnodostępnych danych, a mianowicie statystyce dojazdów do pracy najemnej oraz migracji wewnętrznych na pobyt stały. Jakkolwiek dane te niejednokrotnie stanowiły podstawę określania relacji przestrzennych oraz ich natężenia, to w przypadku niniejszego opracowania zaproponowano autorskie podejście do ich zestawienia oraz opracowania. Identyfikację obszarów intensywnych powiązań funkcjonalnych przeprowadzono dla jednostek tego samego poziomu hierarchicznego. Zbiór miast na prawach powiatu, ze względu na liczbę ludności, jest wewnętrznie zróżnicowany. Zawiera jednak jednostki należące do tego samego poziomu podziału terytorialnego ${ }^{1}$, co jest istotne w przypadku realizacji celu opracowania. Identyfikacja obszarów intensywnych powiązań funkcjonalnych jest wypadkową: (1) obszarów emigracji i imigracji miasta na prawach powiatu, dla których odpowiednio jest on źródłem i celem migracji wewnętrznych na pobyt stały; (2) obszarów wyjazdów i dojazdów do pracy, do i z danego miasta na prawach powiatu, przy uwzględnieniu dodatkowych warunków dotyczących relacji pomiędzy wielkościami przepływów i przepływów powrotnych w układzie miasto na prawach powiatu - obszar wiejski.

W polskiej geografii społeczno-ekonomicznej przez długi czas funkcjonowało jako dominujące pojęcie ruchliwości przestrzennej. Gawryszewski (1989) pod tym pojęciem rozumie wszelkie przemieszczenia przestrzenne ludności, które mają podłoże społeczne, ekonomiczne, kulturalne, bez względu na charakter ruchu, jego czas trwania, przebyty dystans i przyczynę. Tak szerokie rozumienie uznać należy za tożsame z mobilnością przestrzenną (mobility), dla której Kaufmann (2002) wyróżnia cztery podstawowe jej typy. Jest to mobilność: krótkoterminowa wewnątrz regionu zamieszkania² (mobilność codzienna - dojazdy do pracy, szkoły), krótkoterminowa na zewnątrz regionu zamieszkania (podróże służbowe, turystyka), długoterminowa wewnątrz regionu zamieszkania (zmiana mieszkań/domów), długoterminowa na zewnątrz (migracje).

Analizy mobilności, w tym ich jakość, ściśle uzależnione są od tego, w jaki sposób i na podstawie jakich danych będą prowadzone. W polskich badaniach z tego zakresu najczęściej wskazuje się na oficjalne dane dotyczące dojazdów do pracy i/lub zmian w zameldowaniach (m.in. Hołowiecka, 2002; Śleszyński, 2013a; Kurek et al., 2015; Bartosiewicz, 2016). Codzienne dojazdy do pracy, jako element powiązań funkcjonalnych, są na całym świecie podstawą do klasyfikacji, delimitacji obszarów na potrzeby prowadzenia, kreowa-

\footnotetext{
1 Podobny charakter zróżnicowań dotyczy miast wojewódzkich: czy Warszawa jest takim samym miastem jak pozostałe 15 (17) stolic województw? Czy konurbacja górnośląska, z blisko 2 mln liczbą mieszkańców (miast na prawach powiatu ją tworzących), podobnie jak Trójmiasto (blisko 750 tys.), to jeden organizm, czy ich złożenie? Jednak pomimo złożoności tych układów, zróżnicowania wielkościowego ze względu na przyjęte kryterium ich wydzielenia (poziom hierarchiczny) są one jednorodne (na tym samym poziomie). Zobacz też m.in. Dziewoński i Korcelli (1981), Rykiel (1985), Śleszyński (2014).
}

2 Tłumaczenie terminów zgodne z przyjętym przez Komornickiego (2011). 
nia polityki rozwoju społeczno-gospodarczego (Rakowska, 2014). Należy mieć jednak świadomość, że każda z metod określania wielkości i sposobu dojazdów do pracy ma zarówno wady, jak i zalety (Rosik et al., 2010; Śleszyński, 2012). Potrzebne jest zatem refleksyjne podejście do ich stosowania i wykorzystywania oraz przede wszystkim zrozumienie, co faktycznie prezentuje konkretny zastaw danych, w jaki sposób został pozyskany, jakie są jego ograniczenia interpretacyjne.

Opracowanie może stanowić płaszczyznę dyskusji dotyczącej alternatywnych podejść do identyfikacji obszarów powiązań funkcjonalnych. Poza statystyką dojazdów do pracy (najemnej), można do tego celu wykorzystać statystykę migracji wewnętrznych na pobyt stały. O ile statystyka dojazdów do pracy (najemnej) bezdyskusyjnie jest nośnikiem informacji o mobilności przestrzennej - powiązaniach funkcjonalnych, to statystyka migracji wewnętrznych na pobyt stały jest pośrednim źródłem informacji o zjawisku (zob. Smętkowski et al., 2009a). Jednak posiłkując się zapisami zawartymi w opracowaniu Rządowej Rady Ludnościowej w opisie „Sytuacji demograficznej Polski..." (np. Śleszyński, 2019, 2020), migracje te wskazywane są jako przejaw rejestrowanej mobilności (wewnętrznej) bazującej na zameldowaniach i wymeldowaniach międzygminnych. Oczywiście, dane o dojazdach do pracy w większym stopniu pozwalają na opisywanie mobilności. Jednak występują przesłanki do interpretowania danych o wewnętrznych migracjach stałych jako wskazujących na codzienną mobilność przestrzenną. W identyfikacji powiązań funkcjonalnych istotną rolę pełnią również dojazdy do szkół na poziomie ponadpodstawowym. Niestety polska statystyka publiczna nie publikuje systematycznie danych na ten temat ${ }^{3}$.

Analiz dokonano na poziomie NUTS 5 z pominięciem miast nieposiadających statusu miasta na prawach powiatu. Zaprezentowane podejście ma na celu przedstawienie autorskiej metody identyfikacji obszarów intensywnych powiązań funkcjonalnych z perspektywy mobilności przestrzennej ludności.

\section{Przegląd wybranych podejść delimitacyjnych}

Wyznaczanie obszarów powiazań funkcjonalnych mieści się w szerszym zagadnieniu wyznaczania obszarów oddziaływania jednostek osadniczych. Delimitacje te w zdecydowanej większości dotyczą pojedynczych miast bądź ich grup - jednostek tego samego poziomu hierarchicznego. Syntetycznego przeglądu koncepcji objaśniających oddziaływanie miast na otoczenie dokonał Śleszyński (2015). Niniejsze opracowanie bezpośrednio nawiązuje do koncepcji dziennego systemu miejskiego oraz pośrednio do kilku innych fundamentalnych koncepcji, a mianowicie: funkcjonalnego regionu miejskiego, obszaru metropolitalnego czy aglomeracji. Jak zauważa Śleszyński (2013), zarówno terminologia dotycząca terytorialnej identyfikacji obszarów stref/obszarów oddziaływania, jak i stosowanych podejść do ich identyfikacji jest niezwykle bogata. Szczególną uwagę w dotychczasowych badaniach koncentrowano na miastach dużych. Jednak ze względu na indywidualne założenia oraz dobór wskaźników i kryteriów, delimitacje te na ogół są nieporównywalne między sobą. W chwili obecnej najobszerniejszym zbiorem polskich miast (151), dla których na bazie tych samych kryteriów dokonano delimitacji Funkcjonalnych Obszarów Miejskich, jest zbiór powstały w ramach projektu ESPON 1.4.3 Study on urban functions

\footnotetext{
3 Do połowy 2021 r. GUS opublikował jedynie dane w układzie gminnym o dojazdach do szkół ponadpodstawowych dla miast wojewódzkich dla 2018 r..
} 
(ESPON, 2007). Wyróżniono w niej rdzenie oraz strefy podmiejskie w układzie gminnym. Zaznaczyć należy, że w podejściu tym, ze względu na brak danych w czasie realizacji projektu, w zasadzie nie bazowano na powiązaniach funkcjonalnych (np. dojazdy do pracy) ${ }^{4}$

Jedną z częściej przywoływanych w polskiej literaturze przedmiotu delimitacji obszarów funkcjonalnych jest propozycja Śleszyńskiego (2013) ${ }^{5}$. Dotyczy ona identyfikacji miejskich obszarów funkcjonalnych stolic województw. Opiera się ona na siedmiu wskaźnikach podzielonych na trzy grupy (funkcjonalną, społeczno-gospodarczą, morfologiczną). Delimitacja miała być uniwersalna oraz miała stanowić podstawę wyznaczenia tych obszarów dla pozostałych ośrodków regionalnych, a docelowo wszystkich miast na prawach powiatu. Dotyczyła ona stanu na 2011 r., chociaż w trzech przypadkach dane pochodziły z 2002, 2006, 2009, a w jednym obejmowały okres 2002-2011. W delimitacji tej nie udało się wskazać jednorodnych kryteriów dla wskaźników (dla całego kraju) w celu uzyskania „zadowalającej delimitacji”. Dlatego też zdefiniowane progi wskaźników odnoszono do średniej wojewódzkiej danego wskaźnika i/lub rdzenia. W identyfikacji obszarów przyjęto, że musi on, poza zawieraniem się w granicach administracyjnych danego województwa oraz ciągłością przestrzenną, spełniać co najmniej sześć z siedmiu kryteriów. Warunek spełniania dużej liczby kryteriów wiązał się z jednoczesnym obniżeniem ich wartości progowych. Generalizując, tak wyznaczone obszary funkcjonalne (poza wyróżniającą się Warszawą) zamykały się w tradycyjnie określanej strefie podmiejskiej, którą stanowi pierwszy pas gmin otaczających dane miasto. Autor zaznacza, że jest to minimalny zasięg delimitowanych obszarów. Dlatego też wynik końcowy zasadniczo nie stanowi nowego wkładu do dyskursu na temat wyznaczania obszarów funkcjonalnych dla miast co najmniej stutysięcznych.

Innym podejściem bazującym na wspomnianym ujęciu Śleszyńskiego (2013), ale i na „Kryteriach delimitacji miejskich...” (2013), są propozycje Heffnera i Gibasa (2013, 2015). Rozważono w nich kwestię metropolitalności, obszarów funkcjonalnych oraz ich związków z oddziaływaniem ośrodków subregionalnych. W swoich dociekaniach autorzy bazowali na 25 lub 30 zmiennych ujętych w cztery lub pięć zagadnień. Były to: (1) ludność i ruch ludności; (2) usługi publiczne lub kultura sztuka, sport i rekreacja; (3) nauka i szkolnictwo wyższe; (4) przedsiębiorstwa i rynek pracy; (5) jakość lub warunki życia. Warto zauważyć, że w zestawie danych uwzględniono również te pochodzące spoza oficjalnych źródeł statystycznych ${ }^{6}$. Postępowanie delimitacyjne bazowało na wykorzystaniu metody k-średnich. Poza innym zakresem danych niż u Śleszyńskiego (2013) czy też w „Kryteriach delimitacji miejskich...” (2013), nie łączono „potencjałów” Trójmiasta czy też konurbacji górnośląskiej. Zobiektywizowane podejście nie zapewniło sukcesu delimitacyjnego dla analizowanych jednostek (Opole). Podobna sytuacja miała miejsce w ujęciu Śleszyńskiego (2013), ale nie dotyczyła konkretnych jednostek, a całego ujęcia. Jednak istotne w przedstawionych podejściach jest to, że mamy do czynienia z relatywnie wysokim stopniem subiektywizmu w ocenie zasięgów obszarów funkcjonalnych. Dlatego należy podejmować próby poprawy i obiektywizacji podejść do delimitacji obszarów powiązań funkcjonalnych czy też szerzej - obszarów oddziaływania na poszczególnych poziomach hierarchicznych. Heffner i Gibas $(2013,2015)$ zaznaczają, że dobór danych w całym postępowaniu delimitacyjnym jest kluczowy. Jednak w związku z wąskim zakresem dostępnych danych wybór

\footnotetext{
${ }^{4}$ Podobna sytuacja dotyczy podejścia zaproponowanego przez Smętkowskiego et al. (2009b).

5 Zobacz też „Kryteria delimitacji miejskich...” (2013).

6 Np. Diamenty miesięcznika „Forbes” w 2012 w stosunku do podmiotów gospodarczych zarejestrowanych w systemie REGON.
} 
jest bardzo ograniczony. Ponadto dane te poza opisem poziomu zjawiska powinny zawierać informacje o relacjach zachodzącymi pomiędzy obszarami/jednostkami analizy.

Kolejnym podejściem delimitacyjnym jest algorytm zaproponowany przez Smętkowskiego et al. (2009a, b). W tym przypadku delimitacja poprzedzona jest identyfikacją metropolii w zbiorze 38 miast o liczbie ludności powyżej 90 tys., które pełnią szerszy zakres funkcji niż ośrodki mniejsze. Opierając się na pięciu wskaźnikach opisujących wybrane aspekty metropolitalności ${ }^{7}$ dokonano wydzielenia sześciu klas ośrodków miejskich. Słowne określenie klas jest związane z zasięgiem oddziaływania ośrodków. Delimitacja w zamyśle autorów miała zostać przeprowadzona dla całego zbioru miast. Jednak ze względu na to, że „do delimitacji obszarów metropolitalnych (użyto) wskaźników wynikających z teorii biegunów wzrostu, należy spodziewać się, że najlepsze rezultaty wyznaczenia zasięgów obszarów metropolitalnych zostaną osiągnięte przede wszystkim w przypadku tych miast i zespołów miejskich, które będą zajmować najwyższą pozycję w systemie gospodarczym Polski" (Smętkowski et al., 2009b s. 53). W delimitacji wykorzystano dwa wskaźniki: statyczny ${ }^{8}$ i dynamiczny 9 . Dla obu wskaźników określono wartości progowe, powyżej których miasta i gminy mogą tworzyć obszary metropolitalne. Jak zaznaczają autorzy, poziom i dynamika rozwoju gospodarczego gmin nie są wielkościami, które bezpośrednio wskazują na powiązania funkcjonalne w granicach obszarów metropolitalnych. Jednak wykorzystane wskaźniki zawierają szereg elementów związanych z istnieniem powiązań analizowanych miast z gminami położonymi w ich bliskim sąsiedztwie. W podejściu sformułowano cztery założenia, stwierdzając jednocześnie, że „wysokie wartości wskaźników z bardzo dużym prawdopodobieństwem świadczą o istnieniu intensywnych związków funkcjonalnych między ośrodkiem metropolitalnym i sąsiednimi gminami" (Smętkowski et al., 2009b s. 65). Założenia, które wskazano wcześniej, stanowiły przesłanki do wyznaczenia przybliżonych obszarów metropolitalnych największych miast w Polsce. Metoda delimitacji miała być uniwersalna. Jednak taką nie jest przez fakt wprowadzenia do procesu włączenia miast i gmin do obszary metropolitalnego „kolejnych” zasad: (1) ogólnych - pięciu, (2) operacyjnych - trzech wraz z zasadami przyporządkowania do obszaru metropolitalnego, (3) dodatkowych - czterech. Takiemu ujęciu trudno odmówić cech sformalizowania podejścia. Jednak w mniejszym stopniu ma ono charakter podejścia uniwersalnego, a w większym podejścia arbitralnego. Podobnie jak w ujęciu Śleszyńskiego (2013) Trójmiasto i konurbacja górnośląska (podregion centralny-śląski) były traktowane jako całości - jeden organizm. Ostatecznie autorzy uważają, że obszar metropolitalny powinien być ograniczony do 14 miast na prawach powiatu tworzących podregion, a Trójmiasto „rozbite”. Finalna identyfikacja potencjalnych obszarów metropolitalnych największych ośrodków miejskich ma charakter zachowawczy (por. mapa 7 i 8; Smętkowski et al., 2009b, s. 71, 73). Jednak pomimo wcześniejszego ujęcia zagadnienia oraz danych na nich bazujących i pośrednich

7 (1) funkcje kontrolne i zarządcze - przychody firm z listy 500 tygodnika „Polityka” - 2007; (2) potencjał akademicki - liczba studentów w roku akademickim 2006/2007; (3) potencjał kulturalny - liczba miejsc w kinach - 2006; (4) atrakcyjność zewnętrzna - korzystający z noclegów - 2006; (5) dostępność transportowa - liczba pasażerów w porcie lotniczym - 2006.

8 Dochody własne gminy wraz z udziałem w podatkach państwowych na mieszkańca - 2006.

9 Syntetyczny wskaźnik dynamiki odpowiadający sumie standaryzowanych wartości następujących trzech zmiennych: (1) bilansu migracji w latach 2000-2006 w promilach (na 1000 mieszkańców), (2) zmiana liczby spółek z udziałem kapitału zagranicznego w latach w latach 2002-2006 (na 10000 mieszkańców), (3) zmiana liczby przedsiębiorstw prywatnych (bez spółek z udziałem kapitału zagranicznego) zarejestrowanych w REGON w latach 2002-2006 (na 1000 mieszkańców). 
przesłanek identyfikacji (Smętkowski et al., 2009a, b), delimitacja ta posiada szarszy zakres przestrzenny w stosunku do ujęcia Śleszyńskiego (2013).

W przypadku delimitacji obszarów oddziaływania można obecnie stwierdzić występowanie dwóch grup ich ograniczeń. Pierwsza wynika z nieporównywalności delimitacji. U jej podłoża leży różny co do zakresu merytorycznego i czasowego dobór zmiennych/wskaźników. Druga wynika z formułowanych warunków, zasad, wartości progowych wyników, stosowanych metod - różnej metodologii/metodyki. Celem, do którego dąży każde podejście albo go zakłada, jest uniwersalność metody. Dotychczasowe ujęcia jednak jeszcze go nie zrealizowały. Należy stwierdzić, że pomimo „nieporównywalności” metod, podejść czy też zakresu treści, efekt końcowy jest bardzo podobny (praktycznie taki sam). Tym samym należy zadać pytanie: czy to struktury przestrzenne są tak trwałe i niezmienne, czy badacze mają swoje wyobrażenie, do którego dokładają kolejne elementy, tak aby osiągnąć zadowalający rezultat - obraz przestrzenny badanego zjawiska?

\section{Metodyka badań oraz źródła danych}

Identyfikacja obszarów intensywnych powiązań funkcjonalnych została przeprowadzona dla miast na prawach powiatu. Przyjęto dwa założenia. Po pierwsze, miasta na prawach powiatu stanowią zbiorowość jednostek tego samego poziomu hierarchicznego ${ }^{10}$. Po drugie, obszary oddziaływania jednostek wyższych poziomów hierarchicznych są sumą obszarów oddziaływania jednostek niższych poziomów hierarchicznych. Ponadto ograniczono się do przepływów pomiędzy miastami na prawach powiatu, a obszarami wiejskimi (gminy wiejskie, obszar wiejski w gminach miejsko-wiejskich). Pominięto również przepływy pomiędzy miastami (miasta na prawach powiatu-inne miasta na prawach powiatu-pozostałe miasta). Ograniczenie się do obszarów wiejskich ma swoje uzasadnienie w kilku przesłankach. W dojazdach do pracy dominuje kierunek wieś-miasto (47\%). Drugim w kolejności co do udziału jest kierunek miasto-miasto (33\%). Natomiast w dojazdach do pracy pomiędzy miastami dominują przepływy pomiędzy miastami na prawach powiatu, a nie pomiędzy miastami na prawach powiatu z pozostałymi miastami. W przypadku migracji wewnętrznych na pobyt stały, których statystyka bazuje na zarejestrowanych zameldowaniach /przemeldowaniach (zob. np. Śleszyński, 2020), dysproporcje te są mniejsze, Przepływy wieś-miasto, miasto-wieś obejmują łącznie blisko 60\% migracji, z dominacją kierunku miasto-wieś (34,5\%). Natomiast przepływy pomiędzy miastami na prawach powiatu stanowią 43\%. W wyznaczaniu obszarów migracji oraz obszarów dojazdów do pracy, do i z miasta na prawach powiatu, posłużono się największym przepływem. Zaproponowane podejście nawiązuje do metody największego przepływu Nystuena i Dacey (1961, 1968) (zob. Czyż i Hauke, 2014), z tą jednak różnicą, że nie ustalano wcześniej hierarchii oraz regionów nadrzędnych i podporządkowanych (węzłów i satelitów). Jak zaznaczają Czyż i Hauke (2014), pierwotne ujęcie metody często podlegało modyfikacji, a sama metoda używana była w różnych kontekstach badawczych.

Podstawę wyznaczenia obszarów intensywnych powiązań funkcjonalnych stanowią dwie cechy, a mianowicie: (1) wielkość migracji wewnętrznych na pobyt stały ${ }^{11}$ i (2) wiel-

\footnotetext{
10 Zobacz przypis 1.

11 Oceny wartości interpretacyjnej danych dotyczących statystyki ludności przeprowadzili m.in. Dolińska i Jończy (2020), Gołata (2012), Jończy (2012), Śleszyński (2004, 2011),
} 
kość dojazdów do pracy najemnej ${ }^{12}$. Wyznaczenia obszarów dokonano na podstawie sumy danych ze wszystkich lat. Innymi słowy w całym procesie identyfikacji posłużono się sumą dojazdów do pracy dla lat 2006 (Przepływy ludności..., 2009), 2011, 2016 $6^{13}$ oraz migracji wewnętrznych na pobyt stały z okresu 2002-2017 ${ }^{14}$. Takie agregatowe podejście wynika z faktu, że struktura przestrzenna zjawisk(a) oraz relacje zachodzące w ich/jego obrębie, są stałe w czasie, a zmienia się wolumen, gęstość czy też jego natężenie. Opracowując dane o migracjach wewnętrznych na pobyt stały istotnym jest, że znaki hasza (\#) wskazujące na uwzględnienie tajemnicy statystycznej, zastąpiono przepływem o wartości 1 osoby ${ }^{15}$. W przypadku dojeżdżających do pracy w każdym następnym okresie ich liczba była wyższa i wynosiła dla kolejnych okresów 2,1 (2006); 2,8 (2011); 2,9 mln osób (2016). Jednak trudno jest jednoznacznie odpowiedzieć, co spowodowało te zmiany. Czy była to zmiana metodyki zbierania/opracowywania danych (2006 versus 2011), czy może faktyczny wzrost mobilności, przemieszczeń w relacji dom-miejsce pracy (2011 versus 2016)? Natomiast zauważyć trzeba, że struktura czterech głównych kierunków dojazdów do pracy w okresach badania była praktycznie identyczna (miasto-miasto 33\%; wieś-miasto 47\%; miasto-wieś 12\%; wieś-wieś 33\%).

Wyznaczenie obszarów o intensywnych powiązaniach funkcjonalnych odbywało się w trzech etapach, a gmina (obszar wiejski) zaliczona do tego obszaru musiała spełnić sześć warunków (ryc. 1).

W pierwszym etapie dokonano identyfikacji powiązań miasta na prawach powiatu (rdzenia obszaru) z jego otoczeniem poprzez wskazanie największego przepływu w dwóch wariantach. W pierwszym miasto na prawach powiatu jest celem przemieszczeń. W drugim wariancie miasto na prawach powiatu jest źródłem przepływu. Drugi etap to wyznaczenie iloczynu obszarów dla każdego miasta na prawach powiatu (dojazdów z wyjazdami do pracy; imigracji oraz emigracji). Pozwoliło to na identyfikację obszarów, które z rdzeniem pozostają w maksymalnym powiązaniu, jako źródła i cele przemieszczeń. Trzeci etap to identyfikacja obszarów intensywnych powiązań funkcjonalnych miast na prawach powiatu. Poprzedzony jest on realizacją dwóch kluczowych założeń. W przypadku dojazdów do pracy, z obszarów zidentyfikowanych w kroku drugim, wybrane zostały te jednostki, z których wielkość, liczba dojazdów do pracy do miasta na prawach powiatu (rdzenia) z danego obszaru wiejskiego (gminy) była większa niż liczba wyjazdów do pracy z rdzenia do tejże jednostki. Natomiast w przypadku migracji wybrane zostały te jednostki, z któ-

12 Opis dostępnych źródeł odnośnie statystyk dojazdów do pracy od lat 50. XX w. przedstawiono w opracowaniu Wiśniewskiego (2013). Natomiast krytycznego podejścia do oceny wartości interpretacyjnej danych o dojazdach do pracy najemnej dla 2006 dokonał Śleszyński (2012). Zobacz też Kruszka (2010).

${ }_{13}$ Mając na uwadze fakt, że dane o dojazdach do pracy najemnej były gromadzone według ewoluującej metodologii, to takie agregatowe podejście może wzbudzać wątpliwości natury metodycznej. Jednak należy zaznaczyć, że zarówno korelacja liniowa Pearsona oraz rang Spearmana obliczona pomiędzy poszczególnymi latami, dla miast na prawach powiatu jako celów i źródeł dojazdów każdorazowo wynosi co najmniej 0,90. W przypadku współzależności dla wielkości dojazdów do pracy, kiedy miasta na prawach powiatu są celami dojazdów, siła związku jest nie mniejsza niż 0,98.

14 Dane o migracjach wewnętrznych pochodzą z bazy „Demografia” GUS. W części jej tablic znajdują się „Wyniki badań bieżących”, a wśród tabel wynikowych znajduje się tabela 2g, ukazująca w układzie macierzowym wielkość migracji wewnętrznych na pobyt stały według gminy poprzedniego i obecnego miejsca zamieszkania.

15 Dla wykorzystanych danych o migracjach wewnętrznych na pobyt stały za lata 2002-2017, tajemnica statystyczna w każdym roku „eliminuje” przeciętnie blisko 80 tys. przemieszczeń w skali kraju. W ogólnej liczbie przemieszczeń każdorazowo stanowią one średnio blisko 19\%. Natomiast kiedy w miejsce „pustych pól” (\#) wstawimy minimalny przepływ - jedna osoba - niedoszacowanie przemieszczeń spada do przeciętnego poziomu w nieznaczny sposób przekraczający 4\% ogólnej liczby przemieszczeń. 


\begin{tabular}{|c|c|c|}
\hline $\begin{array}{l}\text { Jednostki / relacje / poziomy } \\
\text { identyfikacji obszarów }\end{array}$ & \multicolumn{2}{|c|}{ Warunki wstępne / założenia / działania / rezultaty } \\
\hline Jednostki & \multicolumn{2}{|c|}{$\begin{array}{c}\text { powiat grodzki } \\
\text { obszar wiejski (gmina wiejska; obszar wiejski w gminie wiejsko-miejskiej) }\end{array}$} \\
\hline Relacje (przepływy) & \multicolumn{2}{|c|}{ obszar wiejski $\longleftrightarrow$ powiat grodzki $\longleftrightarrow$ obszar wiejski } \\
\hline Metoda & \multicolumn{2}{|c|}{ największy przepływ } \\
\hline Dane & $\begin{array}{c}\text { dojazdy do pracy } \\
\text { (suma 2006, 2011, 2016) }\end{array}$ & $\begin{array}{l}\text { migracje wewnętrzne na pobyt stały } \\
\text { (suma 2002-2017) }\end{array}$ \\
\hline \multirow{2}{*}{$\begin{array}{l}\text { I poziom identyfikacji } \\
\text { (powiązania) }\end{array}$} & $\begin{array}{l}\text { dojazdy do powiatu grodzkiego } \\
\text { (jako miejsca pracy) }\end{array}$ & $\begin{array}{l}\text { imigracja do powiatu grodzkiego } \\
\text { (jako miejsca nowego zamieszkania) }\end{array}$ \\
\hline & $\begin{array}{l}\text { wyjazdy z powiatu grodzkiego } \\
\text { (jako miejsca zamieszkania) }\end{array}$ & $\begin{array}{l}\text { emigracja z powiatu grodzkiego } \\
\text { (jako miejsca byłego zamieszkania) }\end{array}$ \\
\hline $\begin{array}{l}\text { II poziom identyfikacji } \\
\text { (maksymalne powiązania) }\end{array}$ & $\begin{array}{l}\text { iloczyn obszarów } \\
\text { (dojazdowych i wyjazdowych) }\end{array}$ & $\begin{array}{l}\text { iloczyn obszarów } \\
\text { (imigracyjnych i emigracyjnych) }\end{array}$ \\
\hline Poziom pośredni (warunek) & $\begin{array}{c}\text { identyfikacja jednostek, w których } \\
\text { strumień dojazdów do pracy } \\
\text { (do powiatu grodzkiego) był większy } \\
\text { niż strumień wyjazdów }\end{array}$ & $\begin{array}{c}\text { identyfikacja jednostek, w których } \\
\text { emigracja z powiatu grodzkiego } \\
\text { (miejsce zamieszkania) był większy } \\
\text { niż strumień imigracji }\end{array}$ \\
\hline $\begin{array}{l}\text { III poziom identyfikacji } \\
\text { (powiązania funkcjonalne) }\end{array}$ & \multicolumn{2}{|c|}{$\begin{array}{l}\text { iloczyn obszarów II poziomu identyfikacji po uwzględnieniu } \\
\text { założenia pośredniego uwzględniającego główny kierunek powiązań } \\
\text { (powiązania funkcjonalne) }\end{array}$} \\
\hline
\end{tabular}

Ryc. 1. Schemat identyfikacji obszarów intensywnych powiązań funkcjonalnych Scheme for the identification of areas of strong functional linkage

rych wielkość emigracji w ruchu wewnętrznym na pobyt stały z miasta na prawach powiatu (rdzenia) do danego obszaru wiejskiego (gminy) była większa niż liczba imigrantów do rdzenia z tejże jednostki. Dla dojazdów do pracy tak sformułowany warunek pośredni (dośrodkowy) jest oczywisty. Natomiast dla migracji na pobyt stały warunek pośredni, mający charakter odśrodkowy, już takim nie jest. Warto zaznaczyć, że wykorzystywanie migracji wewnętrznych na pobyt stały do identyfikacji obszarów o intensywnych powiązaniach funkcjonalnych może wydawać się podejściem nieuzasadnionym, jednak nie niemożliwym. Wynika to z tego, że jest to akt jednorazowy i trwały. Jednak należy odwołać się do dwóch kwestii. Po pierwsze, Gawryszewski (1974) zauważył, że pomiędzy migracjami wahadłowymi a napływem migracyjnym występuje silny związek. Po drugie, dla badań w okresie gospodarki rynkowej należy stwierdzić, że migracje wewnętrzne na pobyt stały mają swój dalszy „przemieszczeniowy ciąg”. Wynika to z faktu, że duża część ludności migrującej z miasta do strefy podmiejskiej to ludzie młodzi, którzy już mają dzieci lub w niedługim czasie będą je mieli oraz nie zrywają zasadniczych związków z rdzeniem (Więcław-Michniewska, 2006; Radwańska, 2009; Łodyga, 2011; Harańczyk, 2015). Zazwyczaj jest to model funkcjonowania polegający na tym, że zamieszkanie jest poza miastem, a praca/szkoła/handel i pozostałe usługi w mieście. Tym samym migracje na pobyt stały pomimo, że są aktem jednorazowym, generują migracje wahadłowe na różnych płaszczyznach. W ten sposób, podobnie jak w przypadku dojazdów do pracy, tworzą one związki funkcjonalne. Ostatecznie obszary podwyższonych powiązań funkcjonalnych są iloczynem obszarów wyznaczonych w etapie drugim, po uwzględnieniu warunku dominującego kierunku przemieszczeń (powiązań). 


\section{Wyniki}

W przypadku migracji z (emigracja) i do (imigracja) miast na prawach powiatu wszystkie obszary wiejskie (gminy wiejskie i obszary wiejskie gmin wiejsko-miejskich) wchodzą w skład jednego z 65 obszarów (ryc. 2). Innymi słowy wyczerpują one przestrzeń całego kraju, czyli każdy obszar wiejski znajduje swoje przyporządkowanie do jednego z miast na prawach powiatu. Wśród tych przemieszczeń znajdują się również przemieszczenia jednostkowe ${ }^{16}$. Dla odpływu migracyjnego (emigracji) było łącznie 237 gmin z jednostkowymi migracjami. Cechą ich występowania jest lokalizacja bezpośrednio przy granicy sąsiadujących ze sobą województw. W różnym nasileniu dotyczy to granic wszystkich województw. Charakterystyczna koncentracja obszarów o niskim napływie migracyjnym z miast na prawach powiatu występuje w województwie podkarpackim i sąsiadującymi z nim województwami (lubelskie, małopolskie, świętokrzyskie). Równocześnie obszary te oddzielają obszar emigracyjny Tarnobrzegu od obszaru(-ów): Kielc, Lublina, Radomia, Rzeszowa i Tarnowa oraz Rzeszowa od Lublina. Podobne rozgraniczanie obszarów emigracji w ramach województwa (w tym przypadku wielkopolskiego) dotyczy Poznania i Kalisza oraz Kalisza i Leszna. Natomiast dla imigracji mamy 48 gmin z jednostkowymi przepływami, które zlokalizowane są w województwach południowych i zachodnich ${ }^{17}$. Generalnie jednostki te położone są bezpośrednio przy granicach sąsiadujących ze sobą województw lub w ich bliskim sąsiedztwie. Blisko jedna trzecia tych jednostek znajduje się przy granicy województwa opolskiego i śląskiego.

Zasadniczo obszary imigracji i emigracji dla powiatów grodzkich zamykają się w granicach danego województwa, w którym są zlokalizowane. Jako przykładowe można tu wymienić województwo kujawsko-pomorskie i lubuskie. W przypadku pozostałych regionów domykanie się obszarów imigracji i emigracji w ich granicach również ma miejsce, jednak nie ma ono idealnego charakteru. Można wskazać na kilka charakterystycznych przykładów. Nie dotyczą one całych województw, a jedynie niektórych miast na prawach powiatu. W tym przypadku są to: Kraków, Warszawa i Wrocław. Tak jak pozostałe, poza Katowicami, miasta wojewódzkie tworzą najbardziej rozległe obszary odpływu i napływu migracyjnego. Różnica polega jednak na tym, że ich oddziaływanie w widoczny sposób wychodzi poza granice województwa. W przypadku Warszawy jest to przejęcie obszaru wschodniej części województwa warmińsko-mazurskiego, północno-wschodniej części lubelskiego, wschodu regionu świętokrzyskiego, zachodniej i południowej części podkarpackiego (emigracja). Natomiast Wrocław sięga swoim oddziaływaniem na powiat kępiński i wieruszowski (odpowiednio: wielkopolskie, łódzkie). Mniejsza skala wyjścia poza region dotyczy Krakowa - jest to sięganie z oddziaływaniem na południową część świętokrzyskiego i zachodnią podkarpackiego. Warto również zauważyć, że w omawianych trzech przypadkach obszary emigracji i imigracji nie są zwarte przestrzennie i przechodzą nad/przez obszary: Radomia, Ostrołęki, Legnicy, Tarnowa.

Nałożenie na siebie obszarów imigracji i emigracji pozwoliło na identyfikację obszarów jednoczesnych największych przepływów powrotnych - maksymalnych powiązań

16 Jednostkowe w tym przypadku to strumienie przemieszczeń mniejsze lub równe 16. Przyjęty próg wynika z faktu, że najmniejszy strumień migracji w danym roku to 1 osoba pomnożona przez liczbę analizowanych lat (16).

17 Bez zachodniopomorskiego, z jednostkowymi wystąpieniami w: lubelskim, pomorskim i świętokrzyskim. 

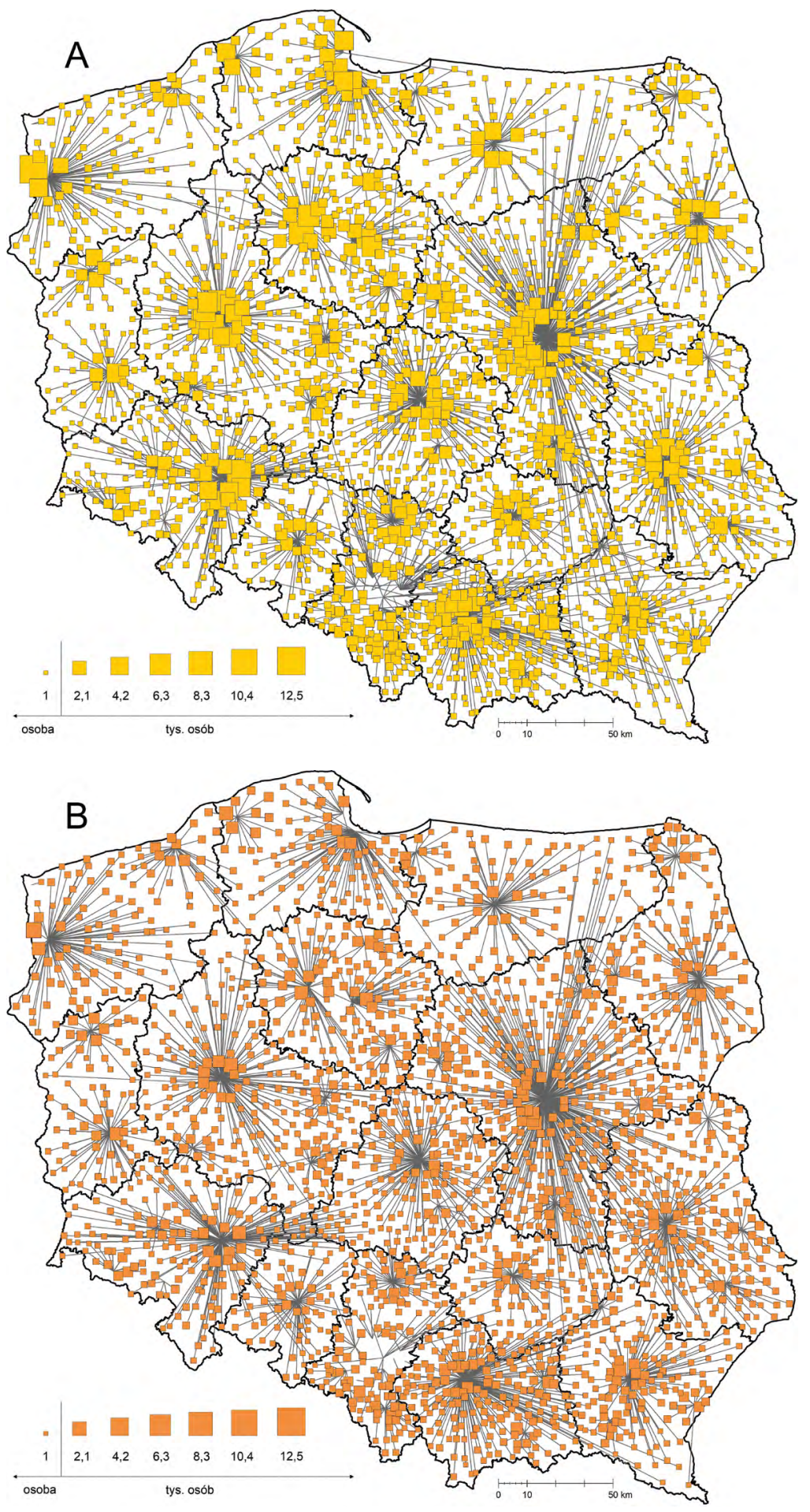


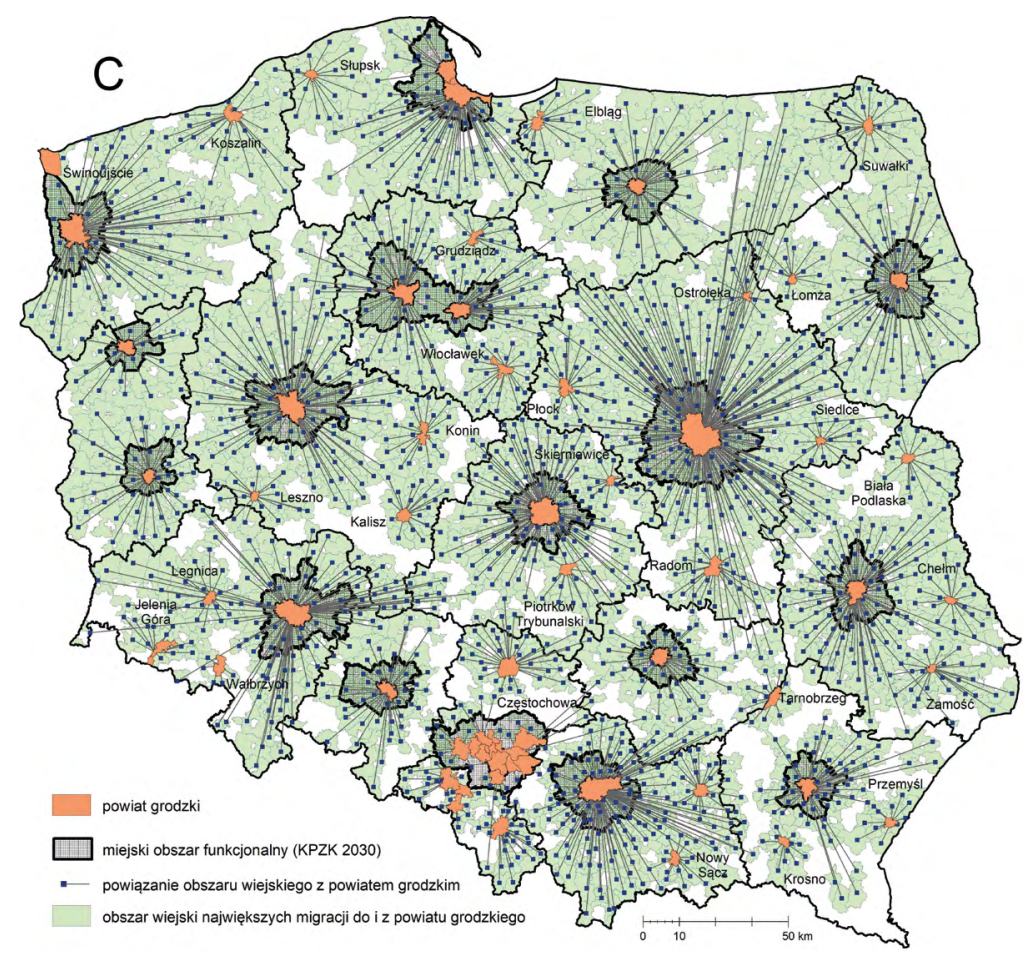

Ryc. 2. Obszary maksymalnych emigracji do miasta na prawach powiatu (A) i imigracji z (B) miasta na prawach powiatu oraz obszary jednoczesnych maksymalnych przepływów powrotnych (C)

Areas of maximal emigration (A) and immigration (B) from and to cities granted county status and areas of simultaneous maximum return flows (C)

Opracowanie na podstawie danych GUS.

- w zakresie migracji wewnętrznych na pobyt stały ${ }^{18}$. Otrzymany obraz jest wypadkową wcześniej zidentyfikowanych obszarów. Obszarów wiejskich niepodwiązanych do żadnego miasta na prawach powiatu było 399. Jest to o 114 więcej niż tych wcześniej zidentyfikowanych jako charakteryzujące się jednostkowymi przepływami. Te spostrzeżenia są o tyle istotne, że jednostki nienależące do napływu lub odpływu migracyjnego, do i z miast na prawach powiatu, występują najczęściej w bliskim sąsiedztwie granic międzyregionalnych. W tym przypadku warto zwrócić uwagę na region podkarpacki, gdzie wyróżnia się obszar maksymalnych powiązań: Rzeszowa, Przemyśla i Krosna. Jednak najbardziej wyraźne jest wyodrębnianie się obszaru Częstochowy od ościennych województw i byłego województwa katowickiego.

Dojazdy do pracy (ryc. 3) zasadniczo domykają się w ramach regionu (Bul, 2015; IInicki i Michalski, 2015). Dotyczy to zarówno dojazdów do miasta na prawach powiatu, jak i wyjazdów do pracy z niego. Poza tym ośrodki regionalne ze swoim oddziaływaniem „nie przechodzą" przez/nad obszarem (obszarami) dojazdów do pracy ośrodków subre-

18 Sześć miast na prawach powiatu nie wykształciło obszaru swojego napływu i odpływu migracyjnego na pobyt stały: Sopot, Chorzów, Ruda Śląska, Siemianowice Śląskie, Świętochłowice, Zabrze. Kolejnych pięć miało ten obszar składający się z jednej gminy wiejskiej: Świnoujście, Jaworzno, Mysłowice, Piekary Śląskie, Żory. 

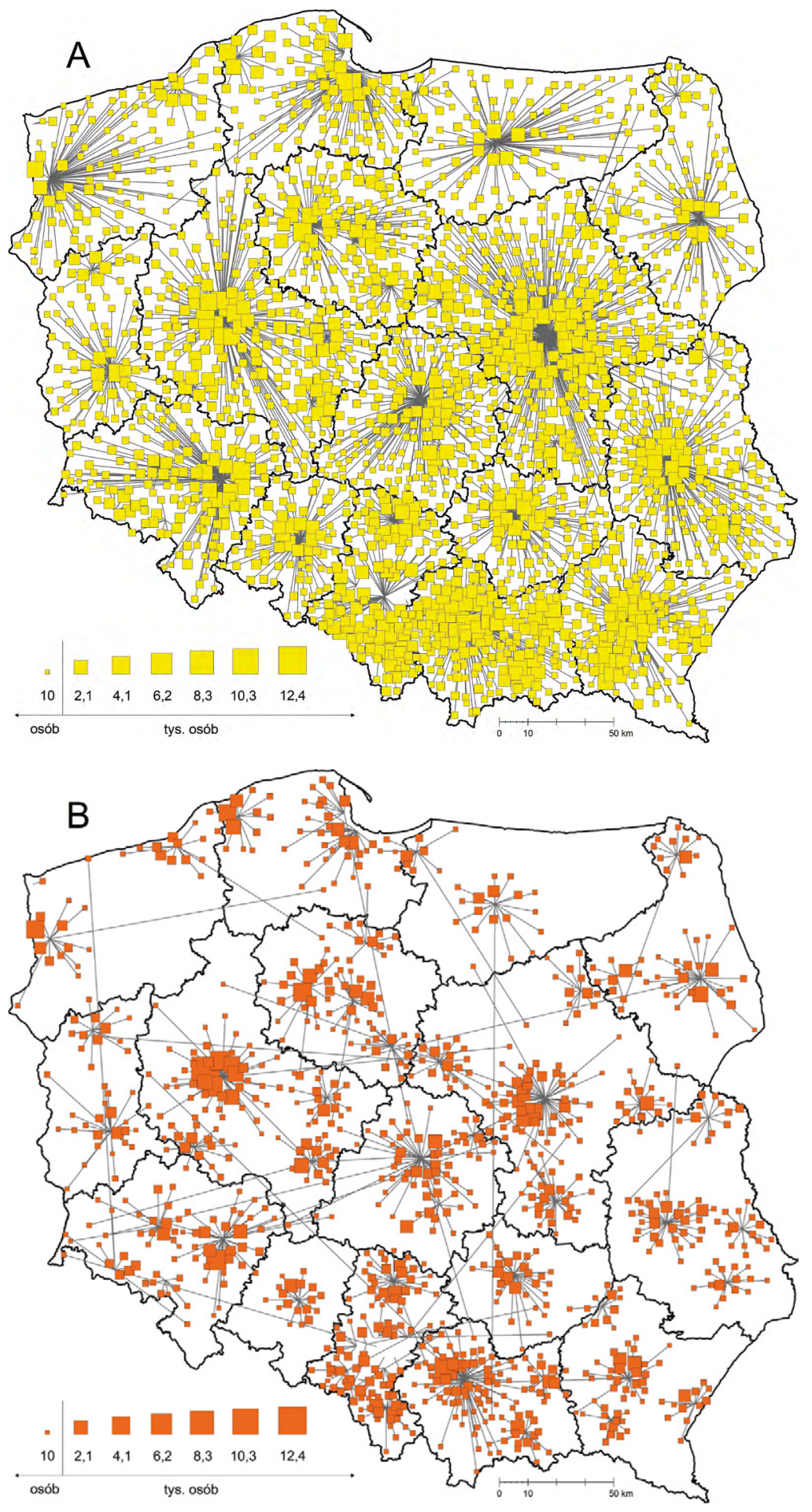


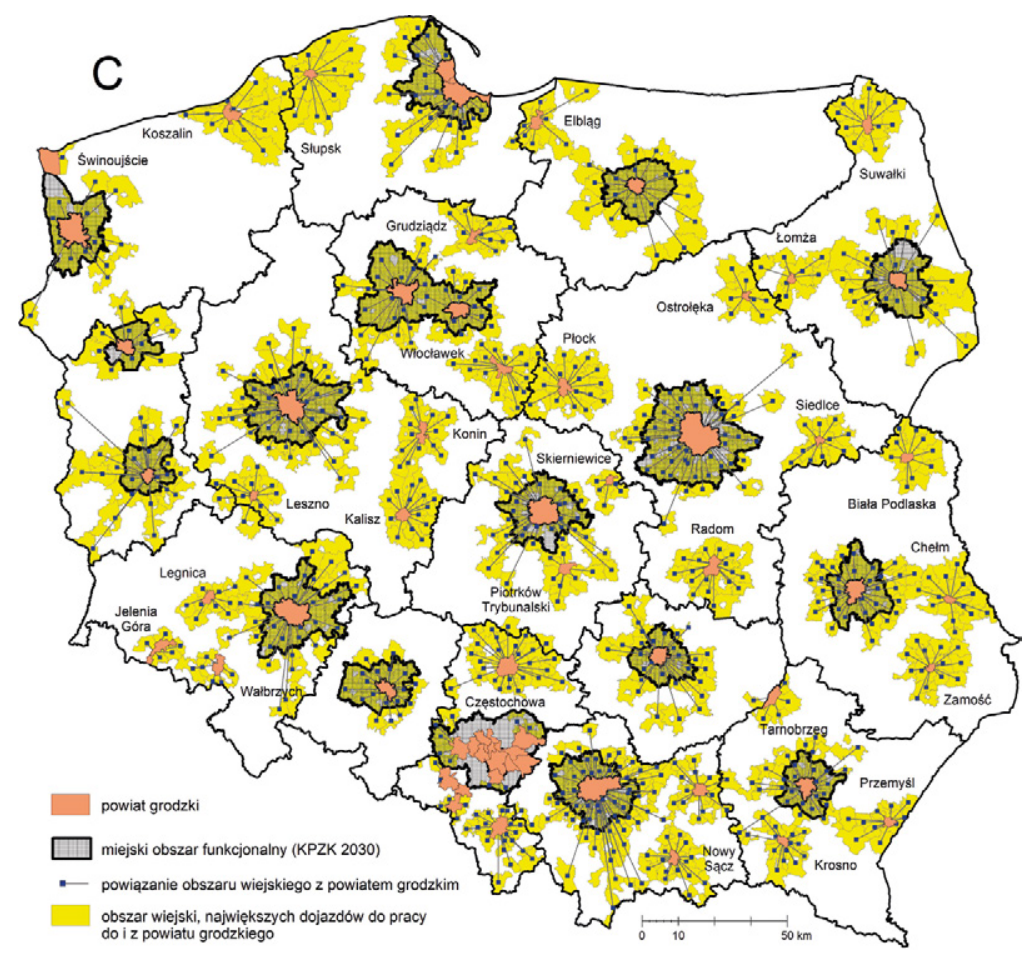

Ryc. 3. Obszary maksymalnych dojazdów do powiatu grodzkiego (A) i wyjazdów z powiatu grodzkiego (B) oraz obszary jednoczesnych maksymalnych przepływów powrotnych (C) w zakresie dojazdów do pracy Areas of maximal commuting to $(A)$ and from (B) cities granted county status and areas of simultaneous maximal return flows in terms of commutes to work

Opracowanie na podstawie danych GUS.

gionalnych (pozostałe miasta na prawach powiatu) ${ }^{19} \mathrm{~W}$ przypadku dojazdów do pracy, podobnie jak dla migracji na pobyt stały, mamy do czynienia z sytuacją, w której do miast na prawach powiatu dojeżdżają pracownicy najemni ze wszystkich obszarów wiejskich kraju. Jednostkowe strumienie ${ }^{20}$ dojazdów to tylko 34 obszary wiejskie, w rozmieszczeniu których nie występują prawidłowości przestrzenne. Natomiast z diametralnie różną sytuacją co do zasięgu przestrzennego, jak i jednostkowych strumieni, mamy do czynienia w przypadku wyjazdów do pracy z miast na prawach powiatu. W zasięgu dojazdów do pracy z miast na prawach powiatu znajduje się $46 \%$ obszarów wiejskich, z których blisko $30 \%$ (296) to jednostkowe strumienie dojazdów (wyjazdów) do pracy. Są one charakterystyczne nie dla lokalizacji znajdujących się blisko rdzenia obszaru, a raczej maksymalnie oddalonych od niego. Jednak, poza nielicznymi przypadkami, nie są one oddalone od centrum rdzenia w linii prostej więcej niż $30 \mathrm{~km}$. Największe wartości dojazdów (wyjazdów) do pracy z miasta na prawach powiatu dotyczą bezpośredniego jego otoczenia. Prawidłowość

19 Wyjątek stanowi: Wrocław-Legnica; Lublin-Zamość; Łódź-Piotrków Trybunalski; Poznań-Konin.

20 Za jednostkowe strumienie przemieszczeń przyjęto te mniejsze lub równe 30. Przyjęty próg wynika z faktu, że najmniejszy strumień dojazdów w danym roku to 10 osób pomnożona przez liczbę analizowanych lat (3). 
ta jest widoczna w przypadku wszystkich rozpatrywanych jednostek, a w szczególności jest to zauważalne dla: Częstochowy, Krakowa, Lublina, Poznania, Rzeszowa, Warszawy.

Jednoczesne maksymalne strumienie dojazdów do i z miast na prawach powiatu maksymalne powiązania - tworzą obszary o zróżnicowanym stopniu zwartości, ciągłości oraz rozciągłości przestrzennej. Brak ciągłości przestrzennej jest charakterystyczny dla ośrodków regionalnych (np. Białystok, Kraków, Łódź, Poznań, Warszawa). Również dla tej grupy jednostek mamy do czynienia z większą strefą dojazdów do pracy oraz złożonym i nieciągłym ich charakterem. Generalnie obszary maksymalnych strumieni dojazdów są izolowanymi układami, jednak w niektórych przypadkach mamy do czynienia z ich stykaniem się (np. Bydgoszcz-Toruń, Kalisz-Konin, Koszalin-Słupsk, Legnica-Wrocław). Większa liczba miast na prawach powiatu, inaczej niż to miało miejsce w przypadku migracji, nie wytworzyła swojego obszaru dojazdów do pracy. Są to te same miasta co w przypadku migracji wraz z sześcioma kolejnymi (Bytom, Jaworzno, Katowice, Mysłowice, Piekary Śląskie, Sosnowiec, Żory). Pomijając Sopot, miasta na prawach powiatu, które nie wytworzyły obszarów migracyjnych czy dojazdów do pracy, pochodzą z województwa śląskiego. W tym województwie tylko dwa miasta (siedziby byłych województw, Bielsko-Biała i Częstochowa) o „peryferyjnym” położeniu wykształciły wyraźne obszary migracji i dojazdów. Poza skrajnie położoną Dąbrową Górniczą, Gliwicami i Tychami, w granicach miejskiego obszaru funkcjonalnego Katowic lub Górnośląsko-Zagłębiowskiej Metropolii Silesia, tylko Jastrzębie-Zdrój i Rybnik posiadają zalążki obszarów dojazdów do pracy. Jak już wspomniano, obszary dojazdów do pracy do powiatów grodzkich, w stosunku do wyjazdów z nich są bardziej rozległe przestrzennie. Wynika to z selektywnego charakteru wyjazdów do pracy z miast na prawach powiatu, przejawiającą się wyjazdami na niewielkie odległości (por. ryc. 2 i 3). Jednak pomiędzy ich rozległością, mierzoną liczbą obszarów wiejskich, występuje bardzo silna korelacja liniowa Pearsona $\left(r_{i j}=0,881\right)^{21}$. Dodatkowo rozległość tych obszarów jest uwarunkowana wielkością miasta na prawach powiatu wyrażoną liczbą ludności ${ }^{22}$.

Zauważyć należy, że granice obszarów funkcjonalnych miast wojewódzkich wpisują się w zasięgi przestrzenne maksymalnych powiązań strumieni dojazdów do pracy do i z miast na prawach powiatu. Wszystkie obszary funkcjonalne zawierają się w granicach zidentyfikowanych obszarów. Tylko w przypadku nielicznych obszarów funkcjonalnych mamy do czynienia z sytuacją, że obszary wiejskie nie zostały włączone w ich granice. Jednak każdorazowo są to jednostkowe przypadki ${ }^{23}$. Wszystkie one zlokalizowane są przy/na granicy obszaru funkcjonalnego.

Obszary maksymalnych dojazdów do pracy determinują rozległość obszarów intensywnych powiązań funkcjonalnych dla miast na prawach powiatu. Znajduje to swoje potwierdzenie w fakcie, że dodanie warunku, że dojazdy do pracy do miasta na prawach powiatu są większe niż wyjazdy z niego, spowodowało spadek liczby obszarów wiejskich tworzących takie obszary z 824 do 807 . Odmienna sytuacja ma miejsce w przypadku obszarów jednoczesnych maksymalnych powiązań w zakresie migracji wewnętrznych na pobyt stały. Po dodaniu warunku, że odpływ migracyjny ma być większy niż napływ migracyjny, rozległość przestrzenna jednoczesnych maksymalnych przepływów powrot-

\footnotetext{
${ }^{21}$ Korelacja rang Spearmana wynosi 0,905.

22 Korelacja linowa Pearsona dla migracji wewnętrznych na pobyt stały i dojazdów do pracy wynosi odpowiednio 0,918 i 0,758.

${ }^{23}$ Białystok (Czarna Białostocka), Łódź (Tuszyn), Szczecin (Nowe Warpno), Warszawa (Jaktorów).
} 
nych zmniejsza się z 1844 do 755 jednostek (ryc. 4). Ostatecznie iloczyn tak zdefiniowanych obszarów, uwzgledniających kierunki powiązań, zmniejszył się do 517. W większym stopniu niż w przypadku maksymalnych strumieni dojazdów do pracy, do i z miast na prawach powiatu, mamy do czynienia z sytuacjami, że dany obszar wiejski nie tworzy obszaru funkcjonalnego miasta na prawach powiatu. Jednak należy stwierdzić, że zaproponowane podejście do identyfikacji obszarów intensywnych powiązań funkcjonalnych co najmniej w dużym stopniu nawiązuje do (z) delimitowanych w ramach Koncepcji Przestrzennego Zagospodarowania Kraju (2011) miejskich obszarów funkcjonalnych ośrodków regionalnych (MOF OR). Brak spełnienia wszystkich warunków, poza wcześniej wskazanymi miastami na prawach powiatu, w granicach zdelimitowanych wcześniej obszarów funkcjonalnych ośrodków regionalnych, dotyczy praktycznie każdego z nich. Jednak w kontekście liczby jednostek je tworzących można mówić o ich zwartości przestrzennej. Z drugiej natomiast strony należy stwierdzić, że obszary funkcjonalne od momentu ich wyznaczenia, uległy i w dalszym ciągu ulegają poszerzeniu (m.in. Czyż, 2011; Kryteria delimitacji miejskich..., 2013, Śleszyński, 2013a).

Obszary intensywnych powiązań funkcjonalnych wychodzą poza obszary funkcjonalne ośrodków regionalnych. Jednak nie jest to regułą. Takie wyjścia poza ich granice są charakterystyczne dla Trójmiasta, Poznania. Łodzi, Krakowa, Wrocławia. Również dla największych ośrodków regionalnych, w przeciwieństwie do pozostałych, widoczna jest przewaga

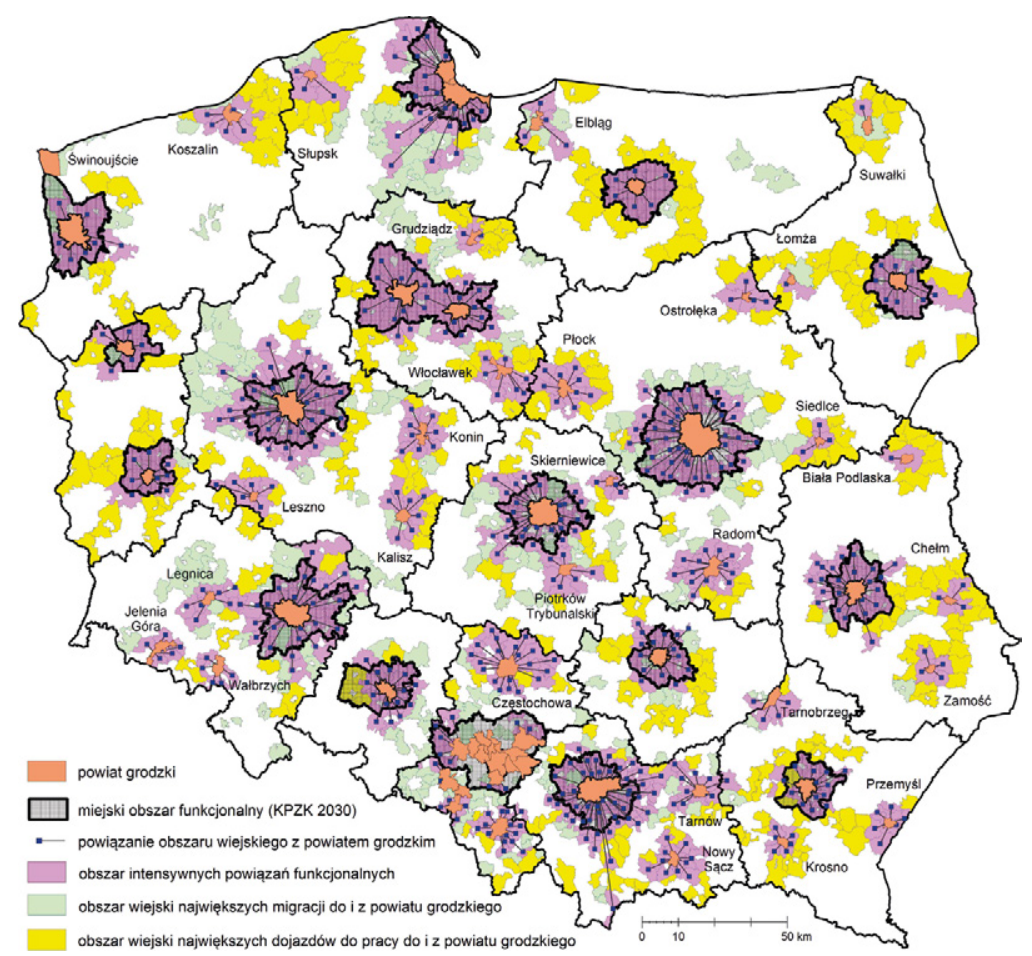

Ryc. 4. Obszary intensywnych powiązań funkcjonalnych powiatów grodzkich Areas of increased functional linkage in cities granted county status Opracowanie na podstawie danych GUS. 
większej liczby maksymalnych powiązań w zakresie migracji niż dojazdów, w otoczeniu obszarów funkcjonalnych. Można przypuszczać, że w niedługiej, pięcio- dziesięcioletniej perspektywie będą się one włączały w intensywne migracje wahadłowe w zakresie pracy i kształcenia na poziomie średnim. Powinny również wpasować się w istniejące oddziaływanie rdzeni w zakresie kształcenia na poziomie wyższym (por. Bul i Kaczmarek, 2016). Obszary największych migracji i dojazdów do pracy (maksymalnych powiązań) w znaczący sposób powiększają obszary intensywnych powiązań funkcjonalnych. Szczególnie obszary maksymalnych powiązań w zakresie dojazdów do pracy mogą być traktowane jako te, które powiększają obszary podwyższonej mobilności przestrzennej - pozostają w trwałych związkach funkcjonalnych z rdzeniem obszaru (por. Bul i Walaszek, 2015).

\section{Podsumowanie}

Głównym celem opracowania była identyfikacja obszarów intensywnych powiązań funkcjonalnych wykorzystująca autorskie podejście do zestawienia i opracowania danych. Wykorzystane do osiągnięcia wyżej wspomnianego celu dane nie stanowią novum na tle dotychczasowych badań. W zestawie danych zasadniczo mamy do czynienia z jedną wielkością, która mówi o powiązaniach funkcjonalnych, migracjach wahadłowych w różnych cyklach, ale też o mobilności przestrzennej. Są nią dojazdy do pracy. Druga z wykorzystanych zmiennych to migracje wewnętrzne na pobyt stały. Zmienna ta w pośredni sposób jest nośnikiem informacji nie tylko o powiązaniach funkcjonalnych, ale również o mobilności przestrzennej (zob. Śleszyński, 2019, 2020). Również ostateczna identyfikacja obszarów intensywnych powiązań funkcjonalnych jest zbieżna z wiedzą na temat nie tylko ich potencjalnej, ale faktycznej rozległości czy też zwartości przestrzennej. Natomiast raczej nie podlega dyskusji, że podejście do ich wyznaczania uwzględniające polską specyfikę kształtowania się omawianych zjawisk jest nowatorskie z co najmniej dwóch powodów. Po pierwsze mamy do czynienia z pokrywaniem się zidentyfikowanych obszarów ze wskazanymi w Koncepcji Przestrzennego Zagospodarowania Kraju 2030 (2011) miejskimi obszarami funkcjonalnymi ośrodków regionalnych. Po drugie, inaczej niż to miało miejsce w różnych podejściach delimitacyjnych, kryteria identyfikacji obszarów nie były warunkowane arbitralnymi decyzjami, np. odnoszeniem analizowanych wielkości do średniego poziomu kształtowania się wartości poszczególnych zmiennych czy też różnym co do liczby analizowanych zmiennych czasowym zakresem danych (np. Kryteria delimitacji miejskich..., 2013; Śleszyński, 2013a; Heffner i Gibas, 2013, 2015). Ponadto, pomijając ośrodki regionalne, w przypadku pozostałych miast na prawach powiatu w wyraźny sposób zarysowują się obszary intensywnych powiązań funkcjonalnych. Są one dodatkowo otoczone jednostkami maksymalnych powiązań, które w zdecydowanej większości są obszarami największych dojazdów do pracy. Na marginesie warto zwrócić uwagę, że podwyższone powiązania funkcjonalne miast na prawach powiatu wschodniej części kraju są zbudowane z mniejszej liczby jednostek niż te z części zachodniej. Jednak wykazują się one dużo większą zwartością przestrzenną. W kontekście występowania maksymalnych powiązań dojazdów do pracy istnieje potencjał do dalszego zwiększenia powiązania tych obszarów.

Istotnym elementem proponowanego podejścia jest jego całkowite zobiektywizowanie, a tym samym wyeliminowanie arbitralnych decyzji, które przy powtarzaniu badań nie muszą mieć miejsca. Poza tym zakres danych, źródła, jak i metodologia ich pozyskania jest 
stała. Należy jednak pamiętać o dopracowywanej metodologii pozyskania i gromadzenia danych o dojazdach do pracy. Przy czym, jak zaznaczono, wielkość strumieni dojazdów do pracy pomiędzy poszczególnymi latami posiada tą samą „strukturę”. Niestety ogólnodostępna statystyka jest pozbawiona innych danych określających wielkość i natężenie relacji pomiędzy miejscami. Można by do nich zaliczyć dane: o terytorialnym pochodzeniu uczniów szkół ponadpodstawowych czy też wyższym; (od) operatorów telefonii komórkowej; organizacji obsługujących płatności bezgotówkowe; (od) operatorów/właścicieli bankomatów o dokonanych transakcjach; o terytorialnym pochodzeniu pojazdów wjeżdżających do miast czy też parkujących w strefach płatnego parkowania itp. Tego typu dane częściowo mogą być nośnikiem informacji o przemieszczeniach incydentalnych, niezwiązanych z rutyną postępowania w długim czasie. W odniesieniu do wyników zaprezentowanych w niniejszym opracowaniu warto podkreślić fakt, że analizy oparte na danych pochodzących z oficjalnych statystyk z założenia informują nas o przemieszczeniach nieincydentalnych. Zmiana miejsca zamieszkania czy dojazdy do pracy posiadają charakter stałości w długim okresie czasu.

Stoimy na stanowisku, że do badań, które aspirują do całościowego rozwiązania zagadnienia, czy to od strony wskaźnikowej, zakresu opisu zjawiska czy zakresu przestrzennego, powinno dopuszczać się ustalenia badań będących studiami przypadków. Takie podejście z jednej strony umacnia wnioski, a z drugiej wskazuje na nową, czy też szerszą perspektywę badawczą. Finalnie warto zwrócić uwagę, że pojawianie się nowych źródeł bezpośrednich i pośrednich danych o mobilności przestrzennej, zwłaszcza codziennej, jest szansą na odwrócenie stanu, który pod koniec XX w. zdiagnozował Taylor (1999): uboga literatura geograficzna odnośnie codziennych przemieszczeń w relacji do literatury o migracjach.

\section{Piśmiennictwo}

Bartosiewicz, B. (2016). Obszary funkcjonalne małych i średnich miast w Polsce - koncepcja badawcza. Studia Ekonomiczne, 279, 234-244.

Bul, R. (2015). Dojazdy do pracy w aglomeracji poznańskiej w 2011 r. Rozwój Regionalny i Polityka Regionalna, 32, 149-172.

Bul, R., \& Kaczmarek, T. (2016). Rola Poznania jako ośrodka metropolitalnego i jego powiązania w województwie wielkopolskim. Rozwój Regionalny i Polityka Regionalna, 36, 73-89.

Bul, R., \& Walaszek, M. (2015). Dojazdy do pracy i szkół jako podstawowe kryterium delimitacji obszarów funkcjonalnych miast. Rozwój Regionalny i Polityka Regionalna, 29, 119-138.

Clark, W.A. (2008). Geography, space, and science: Perspectives from studies of migration and geographical sorting. Geographical Analysis, 40(3), 258-275.

Czyż, T. (2011). Conceptions of an urban agglomeration and a metropolitan area in Poland. Geographia Polonica, 84, 5-17.

Czyż, T. \& Hauke, J. (2014). Zastosowanie metod taksonomicznych w analizie struktury systemu regionalnego. Rozwój Regionalny i Polityka Regionalna, 25, 29-45.

Dolińska, A., \& Jończy, R. (red). (2020). Procesy migracyjne w południowo-zachodniej Polsce w kontekście sytuacji na rynku pracy. Wybrane zagadnienia. Wrocław: Wydawnictwo Uniwersytetu Ekonomicznego we Wrocławiu.

Dziewoński, \& K. Korcelli, P. (1981). Studia nad migracjami i przemianami systemu osadniczego w Polsce, Prace Geograficzne, 140, Warszawa: Instytut Geografii i Przestrzennego Zagospodarowania PAN. 
ESPON. (2007). Study on Urban Functions. ESPON Project 1.4.3. Final Report, ESPON Coordination Unit, Luxembourg. Pobrane z: https://www.espon.eu/programme/projects/espon-2006/studies-and-scientific-support-projects/study-urban-functions (12.05.2021).

Gawryszewski, A. (1974). Zwiq̨zki przestrzenne między migracjami stałymi i dojazdami do pracy oraz czynniki przemieszczeń ludności, Prace Geograficzne, 109. Warszawa: Instytut Geografii i Przestrzennego Zagospodarowania PAN.

Gawryszewski, A. (1989). Przestrzenna ruchliwość ludności Polski 1952-1985. Prace Habilitacyjne. Warszawa: Instytut Geografii i Przestrzennego Zagospodarowania PAN.

Gołata, E. (2012). Spis ludności i prawda. Studia Demograficzne, 161(1), 23-55.

Harańczyk, A. (2015). Procesy suburbanizacji w Krakowskim Obszarze Funkcjonalnym. Studia Miejskie, 18, 85-102.

Heffner, K., \& Gibas, P. (2013). Poziom metropolitalności wybranych ośrodków w Polsce - znaczenie wag i zmiennych. W: J. Suchecka (red.), Ekonometria przestrzenna i regionalne analizy ekonomiczne (s. 11-26). Acta Universitatis Lodziensis, Folia Oeconomica, 293. Łódź: Wydawnictwo Uniwersytetu Łódzkiego.

Heffner, K., \& Gibas, P. (2015). Obszary funkcjonalne i ich związki z zasięgiem oddziaływania z ośrodków subregionalnych (na przykładzie województwa opolskiego). Studia Miejskie, 18, 9-24.

Hołowiecka, B. (2002). Strefa wpływu Torunia na podstawie dojazdów do pracy. Biuletyn Geograficzny, 1, 251-262.

Ilnicki, D., \& Michalski, P. (2015). Powiązania funkcjonalno-przestrzenne w świetle dojazdów do pracy. Studia Miejskie, 18, 55-70.

Jończy, R. (2012). (Nie) przydatność danych statystycznych oraz opartych na nich diagnoz i prognoz społeczno-gospodarczych w kontekście występowania nierejestrowanej emigracji stałej (emigracji zawieszonej). W: Polityka społeczna, kontynuacja i zmiana (s. 247-262). Studia i Monografie. Warszawa: Instytut Pracy i Spraw Socjalnych, 2012.

Kaufmann, V. (2002). Re-thinking mobility. New York: Ashgate.

Komornicki, T. (2011). Przemiany mobilności codziennej Polaków na tle rozwoju motoryzacji. Prace Geograficzne, 227. Warszawa: Instytut Geografii i Przestrzennego Zagospodarowania PAN.

KPZK 2030. (2011). Koncepcja Przestrzennego Zagospodarowania Kraju 2030. Warszawa: Ministerstwo Rozwoju Regionalnego.

Kruszka, K. (red). (2010). Dojazdy do pracy w Polsce. Terytorialna identyfikacja przepływów ludności zwiqzanych z zatrudnieniem. Poznań: Ośrodek Statystyki Miast Urzędu Statystycznego w Poznaniu.

Kryteria delimitacji miejskich obszarów funkcjonalnych ośrodków wojewódzkich. (2013). Warszawa: Ministerstwo Rozwoju Regionalnego.

Kurek, S., Wójtowicz, M., \& Gałka, J. (2015). Powiązania funkcjonalno-przestrzenne w Krakowskim Obszarze Metropolitalnym w świetle dojazdów do pracy. Studia Miejskie, 18, 71-84.

Łodyga, B. (2011). Demograficzne skutki suburbanizacji w aglomeracji poznańskiej. Studia Miejskie, 3, 113-138.

Nystuen, J.D., \& Dacey, M.F. (1961). A graph theory interpretation of nodal regions. Papers, Regional Science Association, 7, 29-42.

Nystuen, J.D., \& Dacey, M.F. (1968). A graph theory interpretation of nodal regions. Geographia Polonica, 15, 135-151.

Przepływy ludności związane z zatrudnieniem w Polsce w 2006 r. (2009). Pobrane z: http://stat.gov. $\mathrm{pl} /$ statystyka-regionalna/badania-regionalne/przeplywy-ludnosci-zwiazane-z-zatrudnieniem-wpolsce-w-2006-r-3060/ (14.12.2020) 
Radwańska, M. (2009). Ciążenie ludności do ośrodka rdzeniowego aglomeracji, na przykładzie Torunia. W: W. Maik (red.), Aglomeracje miejskie w Polsce na przełomie XX i XXI wieku, Problemy rozwoju, przekształceń strukturalnych i funkcjonowania (s. 333-346). Bydgoszcz: Wyższa Szkoła Gospodarki w Bydgoszczy.

Rakowska, J. (2014). Codzienne dojazdy do pracy jako ekonomiczne kryterium rządowych klasyfikacji i delimitacji obszarów (na przykładzie USA i Kanady). Studia Regionalne i Lokalne, 57(15), 46-59.

Rosik, P., Stępniak, M., \& Wiśniewski, R. (2010). Dojazdy do pracy do Warszawy i Białegostoku - alternatywne podejścia metodologiczne. Studia Regionalne i Lokalne, 40(2), 77-98.

Rykiel, Z. (1985). Zagadnienia regionalnych systemów osadniczych. Studia KPZK PAN, 88. Warszawa: PWN.

Rzeszewski, M., \& Rodak, O. (2019). Czy więcej znaczy lepiej? Badania ilościowe w geografii społeczno-ekonomicznej ery Big Data. Rozwój Regionalny i Polityka Regionalna, 46, 67-89.

Smętkowski, M., Gorzelak, G., \& Jałowiecki, B. (2009a). Obszary metropolitalne w Polsce - diagnoza i rekomendacje. Studia Regionalne i Lokalne, 35(1), 52-73.

Smętkowski, M., Gorzelak, G., \& Jałowiecki, B. (2009b). Obszary metropolitalne w Polsce: problemy rozwojowe i delimitacja. Raporty i analizy EUROREG 1/2009. Warszawa: Centrum Europejskich Studiów Regionalnych i Lokalnych, Uniwersytet Warszawski.

Shelton, T., Poorthuis, A., \& Zook, M. (2015). Social media and the city: Rethinking urban socio-spatial inequality using user-generated geographic information. Landscape and Urban Planning, $142,198-211$.

Śleszyński, P. (2004). Regionalne różnice pomiędzy liczbą ludności według Narodowego Spisu Powszechnego w 2002 roku i szacowaną na podstawie ewidencji bieżącej, Studia Demograficzne, 145(1), 93-103.

Śleszyński, P. (2012). Kierunki dojazdów do pracy. Wiadomości Statystyczne, 11, GUS, Warszawa, 59-75.

Śleszyński, P. (2013a). Delimitacja Miejskich Obszarów Funkcjonalnych stolic województw. Przegląd Geograficzny, 85(2), 173-197.

Śleszyński, P. (2013b). Warszawa jako ośrodek dojazdów pracowniczych. Studia Regionalne i Lokalne, 51(1), 5-25.

Śleszyński, P. (2015). Problemy delimitacji miejskich obszarów funkcjonalnych w Polsce. Rozwój Regionalny i Polityka Regionalna, 29, 37-53.

Śleszyński, P. (2019). Migracje wewnętrzne. W: Sytuacja demograficzna Polski. Raport 2018-2019 (s. 124-170). Warszawa: Rządowa Rada Ludnościowa.

Śleszyński, P. (2020). Migracje wewnętrzne. W: Sytuacja demograficzna Polski. Raport 2019-2020 (s. 171-206). Warszawa: Rządowa Rada Ludnościowa.

Taylor, Z. (1999). Przestrzenna dostępność miejsc zatrudnienia, kształcenia i usług a codzienna ruchliwość ludności wiejskiej. Prace Geograficzne, 171. Warszawa: Instytut Geografii i Przestrzennego Zagospodarowania PAN.

Więcław-Michniewska, J. (2006). Krakowskie suburbia i ich społeczność. Kraków: Uniwersytet Jagielloński.

Wiśniewski, R. (2013). Społeczno-demograficzne uwarunkowania dojazdów do pracy do Białegostoku, Prace Geograficzne, 244. Warszawa: Instytut Geografii i Przestrzennego Zagospodarowania PAN. 


\section{Summary}

Spatial mobility of the population is a key factor allowing for the delimitation of functional areas and the identification of ranges of impact of given spatial units. The work detailed here has built on this idea by seeking to identify areas of strong functional linkage in the cities in Poland that have been granted the status of powiat (i.e. unit at the "county" level of administration). In this context, the paper also offers a critical analysis of other, best-known approaches to the delimitation of towns and cities in Poland. The identification of areas characterised by strong functional linkage is achieved by reference to generally-available data, i.e. statistics relating to commutes to work, as well as internal migration leading to permanent residency status. Overall, areas of srong functional linkage are here delimited by reference to: (1) areas of emigration or immigration relating to thecities granted county status, where these are the source and/or destination when it comes to internal migration leading to permanent residency; (2) areas of departure and arrival where commutes to and from the aforesaid cities granted county status are concerned, with account taken of additional relations relating to volumes of flows in a 'city-rural area' configuration. Our analysis was performed at NUTS-5 level, hence the exclusion of cities not enjoying county status. It is against the background of existing literature reports on means of identifying areas of functional linkage for Polish cities that the work detailed here may establish a basis for discussing alternative approaches. Here the authors offer their own method of identifying areas of strong functional linkage, from the point of view of people's spatial mobility. This approach takes account of specifically Polish aspects of the phenomenon's development. Indeed, analyses confirm that the approach proposed is very much linked to the functional urban areas of regional centres. However, complete objectivisation (i.e. a lack of subjectivity or even arbitrary decisions) represents a significant attribute of the approach in question, with this being desirable when it comes to research being replicated. 